\title{
CONCRETE COMPOSITION ANALYSIS CAST AS A PLATE SOLAR RADIATION
}

\author{
N.R. Ismail ${ }^{1}$, N. Fuhaid ${ }^{2}$ \\ ${ }^{I}$ Mechanical Engineering Departement.Engineering Faculty. Widyagama of University, Jl. Taman Borobudur indah \\ no 3, Malang, East Java, Indonesia \\ ${ }^{2}$ Mechanical Engineering Departement.Engineering Faculty. Widyagama of University, Jl. Taman Borobudur indah \\ no 3, Malang, East Java, Indonesia
}

\begin{abstract}
Various studies have been conducted relating to the material heat absorption and using. This study is a continuation of the research material concrete (cement, sand and stones cast) that produce; cement is kind of best cement Puger-Jember, finest sand is sand and stones cast iron is best cast stone(split). From these studies continued to receive concrete composition which can improve the performance of concrete as a heat absorber plate of solar radiation. In this study, using an experimental method to test the composition of concrete (cement, sand and stones cast) Testing is done by testing the compressive strength without and with heat treatment, the ability to absorb heat and heat dissipation, and test the ability to absorb and store the sun's heat radiation. Research produces the best concrete composition is the composition of the 2-2-3 concrete compressive strength in the review of the heat treatment, heat treatment and reduction in heat and heat of solar radiation absorption
\end{abstract}

Keywords: composition of concrete, compressive strength, capable of heat absorber

\section{INTRODUCTION}

\subsection{Background}

Collector / absorber plate serves to absorb heat and is a very important component in the system heat absorption of solar radiation. Various studies conducted to improve the efficiency of absorption of heat collector is used to improve the efficiency of heat absorption in accordance with the application.

According to Rahmat (2001), with a copper absorber plates are coated with matte black paint has a heat absorption coefficient of 0.82 and with the addition of gravel on top of it can improve the efficiency of solar distillation. Kris and San (2001), said that the thicker the absorber plate and the smaller the distance between the collector pipes, fin efficiency of the optimum collector. by Lempoy (2003), the addition of gravel on concrete absorber plate, resulting in productivity and efficiency of daily solar still is higher than without gravel. According Moninja (2004), collector type of concrete can increase the efficiency of solar collectors still higher than copper types. Ismail (2007), examined the absorber plate type concrete, aluminum, zinc and copper in the solar heater, produces the highest temperature absorber plate is a type of bronze, its steady heat absorption efficiency is a type of concrete. According to La Aba (2008), said the wave absorber plate and the thicker, more effective way to improve the performance of solar still. Ismail and Aditya (2010), a mixture of concrete type absorber plate with 2 parts cement composition, fine aggregate (sand) and 2 parts coarse aggregate (stone cast / coral) 3 parts produces the highest heat absorption efficiency compared to other compositions, and absorber plate with a thickness of $5 \mathrm{~cm}$ having the highest thermal efficiency of absorption compared with the thickness of 2.5 $\mathrm{cm}, 7.5 \mathrm{~cm}$ and $10 \mathrm{~cm}$. Ismail and Fuhaid (2012), the best type of sand is a type of sand and stones cast iron is the best kind of cast stone split / celebrity, if in the review of the heavier kind, capable of heat treatment, and heat absorption of solar radiation and heat storage. The type or brand of cement is best-Jember Puger cement type, if in the review of the mortar compressive strength, capable of heat treatment, and heat absorption of solar radiation and heat storage. Based on the research that has been done on the basis of material / raw material, it is necessary to study the composition of concrete as a heat sink plate solar radiation.

Plate absorber / collector serves to absorb solar radiation and heat is a very important component in solar distillation system and a solar water heater is simple.

\subsection{Solar Collectors}

Based on the shape desired heat temperature heat collector can be broadly grouped into two parts:

1. Centering collector with a low concentration of between $80^{\circ} \mathrm{C}$ to $150^{\circ} \mathrm{C}$.

2. Flat plate collectors for temperatures lower than $80^{\circ} \mathrm{C}$

Collectors Flat Plate Collector Efficiency Value of heat absorption $\left(\alpha_{\mathrm{s}}\right)$ on the absorber plate will maximize the efficiency of solar energy receiver. Absorption efficiency at each observation time interval $(\mathrm{t})$ is defined as the ratio of the heat absorbed energy absorber plate $\left(Q_{u}\right)$ to the amount of heat received by radiation $\left(G_{t}\right)$ by the absorber plate surface $\left(A_{c}\right)$; 


$$
\eta_{s}=\frac{Q_{u}}{A_{c} \cdot G_{T} \cdot t}
$$

Where $\eta_{\mathrm{s}}$ is the efficiency of the absorber plate, while the heat is absorbed by the absorber plate at specified intervals (Duffie and Beckman. 1980):

$$
Q_{u}=m C_{p}\left(T_{p}-T_{i}\right)
$$

So the efficiency of the absorber plate:

$$
\eta_{s}=\frac{m C_{p}\left(T_{p}-T_{i}\right)}{A_{c} \cdot G_{T} \cdot t}
$$

with:

$\mathrm{m}_{\mathrm{p}} \quad=$ The absorber plate $(\mathrm{kg})$

$C_{p}=$ Specific heat absorber plate $\left(\mathrm{kJ} / \mathrm{kg} .{ }^{\circ} \mathrm{C}\right)$

$T_{p}=$ Temperature of the absorber plate end $\left({ }^{\circ} \mathrm{C}\right)$

$T_{i}=$ Temperature initial absorber plate $\left({ }^{\circ} \mathrm{C}\right)$

$\mathrm{G}_{\mathrm{t}}=$ total solar radiation $\left(\mathrm{W} / \mathrm{m}^{2}\right)$

A $=$ The area of the basin $\left(\mathrm{m}^{2}\right)$

$\mathrm{Q}_{\mathrm{u}} \quad=$ heat absorbed energy $(\mathrm{kJ})$

$\mathrm{t} \quad=$ observation time (detik)

Maximum heat absorption occurs when there is no heat loss to the surrounding air is if $\boldsymbol{U}_{\boldsymbol{L}}=0$, so the value panyerapan $\left(\alpha_{s}\right)$ can be determined from the intersection graph with ordinate axis efficiency $\left(\eta_{\mathrm{s}}\right)$. The relationship between the value of efficiency $\left(\eta_{\mathrm{s}}\right)$. absorption values are $\frac{\left(T_{p}-T_{a}\right)}{G_{t}}$ presented in the figure below.

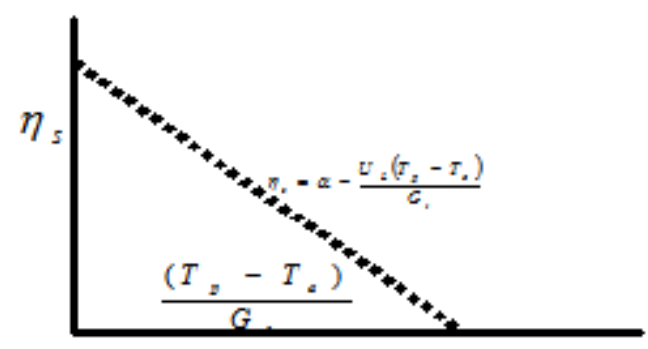

Fig 1 Graph characteristics absorber plate absorption efficiency (Source: Duffie and Beckman. 1980:251)

\subsection{Concrete}

Concrete is a mixture of fine aggregate and coarse aggregate (sand, gravel, crushed stone or other aggregate types) with cement, held together by water in a certain ratio

\subsection{Portland Cement (PC)}

Portland Cement or commonly called hydraulic cement is a binder in the form of a fine powder produced by softening clinker (material is mainly composed of calcium silicates which are hydraulic), with a cast stone as additives.Raw material for making cement are materials containing lime, silica, alumina, iron oxide, and other oxides. If a fine powder is mixed with water, the time can be hard. Mixture of cement with water is called cement paste, if the pasta is mixed with sand will be cement mortar.

\subsection{Aggregate}

Aggregate is a natural mineral grains that serve as filler in concrete mix to fill almost $50 \%$ to $80 \%$ of the volume of concrete, so that the nature and quality of aggregate greatly affect the nature and quality of the concrete. There are two types of aggregate, the fine aggregate (sand) and coarse aggregate (gravel).

1. Sand is divided into three, namely;

a. Sand quarrying, sand type is generally sharp, angular, porous, and free of harmful salt content. But the sand is often mixed with dirt / soil, and should be washed before use.

b. River sand, fine-grained and generally round, the adhesion between the grains is not good.

c. Sea sand, smooth and rounded grain shape. Many contain salt, so it is not good for building

2. Gravel can be divided into two types:

a. Naturally, the stone that comes from natural events such as frozen aggregate

b. Crushed stone, the gravel from the quarry.

The most widely applied to distinguish the type of aggregate, is based on the grain-grains. The use of aggregate in the concrete is to save the use of Portland cement, resulting in great strength on concrete, reduce shrinkage hardening, reaching a solid composition and workability control (trait easy to do).

Gradation of aggregate is aggregate grain size distribution of roughness. Gradation taken from the sifting sieve with holes $10 \mathrm{~mm}, 20 \mathrm{~mm}, 30 \mathrm{~mm}$, and $40 \mathrm{~mm}$ for gravel. For sand pit $4.8 \mathrm{~mm}, 2.4 \mathrm{~mm}, 1.2 \mathrm{~mm}, 0.6 \mathrm{~mm}, 0.3 \mathrm{~mm}$, and $0.15 \mathrm{~mm}$.

\subsection{Water}

The main purpose of the use of water is for hydration occurs, the chemical reaction between the cement with water which causes the mixture becomes hard after a certain time.

\section{METHODS}

\subsection{Stages of Research}

Based on the background and purpose of the study, the research phases can be seen in the following flow chart: 


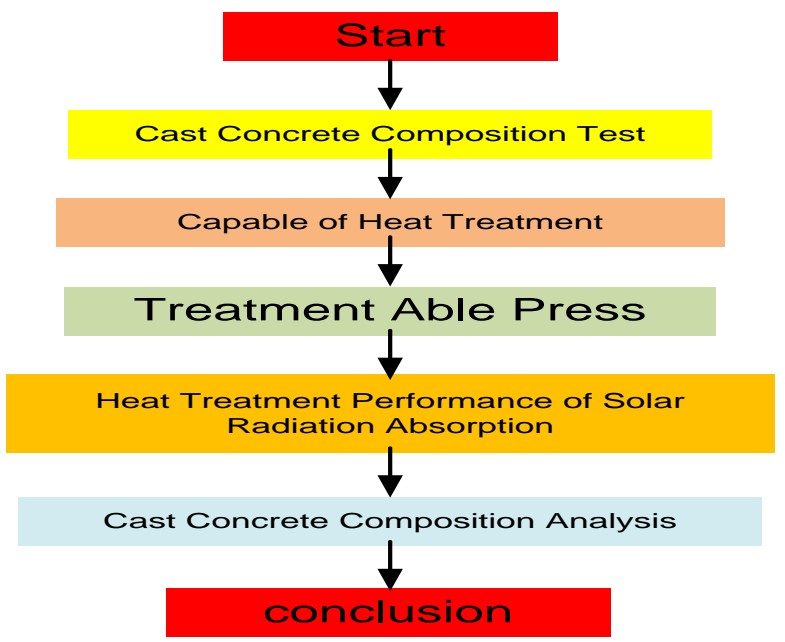

Fig 2 stages of research

\section{Research Tools}

1. Heat absorption of solar radiation testing conducted at the Laboratory of Solar Power and Alternative Energy Department of Mechanical Engineering Faculty of Engineering Brawijaya University Malang. Model test equipment and measuring instruments can be seen in the figure below;

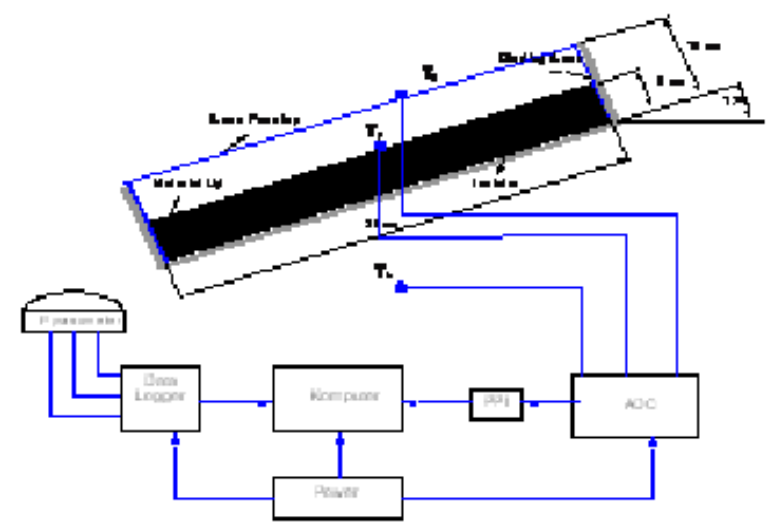

Fig 3 Scheme of solar radiation heat solar test

2 Tests conducted heat. At the Metallurgy Department of Mechanical Engineering University of Malang Widyagama.

3 Testing able to press done. Concrete Laboratory Civil Engineering State Polytechnic of Malang.

\subsection{Testing Time}

In the heat sorption of solar radiation testing, observations were made starting at 7:00 WIB until 6:00 WIB next day,and directly under the sun with the duration of data is done every 10 minutes

\section{RESULTS AND DISCUSSION}

\subsection{Composition of Concrete Compressive Strength}

\section{Testing}

The test is performed to obtain concrete composition with the ability to tap the best. In this test, the composition of concrete using iron sand and iron sand using a mixture of $40 \%$ with $60 \%$ sand lumajang. Before the test press, concrete composition is given heat treatment of the temperature of The test is performed to obtain concrete composition with the ability to tap the best. In this test, the composition of concrete using iron sand and iron sand using a mixture of $40 \%$ with $60 \%$ sand lumajang. Before the test press, concrete composition is given heat treatment of the temperature of $0{ }^{\circ} \mathrm{C}, 200{ }^{\circ} \mathrm{C}, 400{ }^{\circ} \mathrm{C}$ dan $600{ }^{\circ} \mathrm{C}$. The results can be seen in Figure 4, as follows:. The results can be seen in Fig 4, as follows:

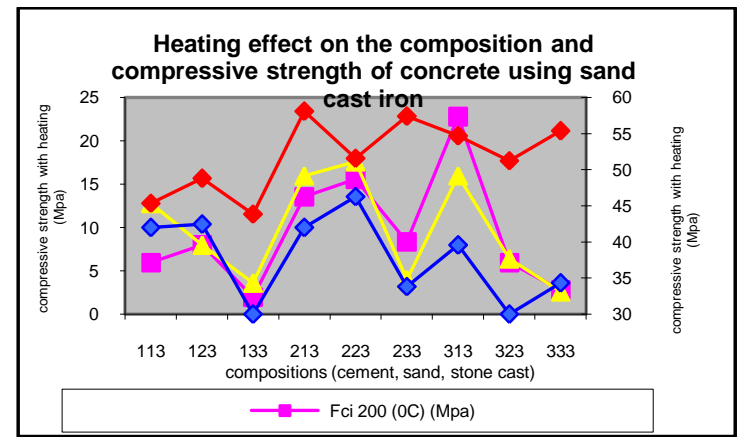

(a)

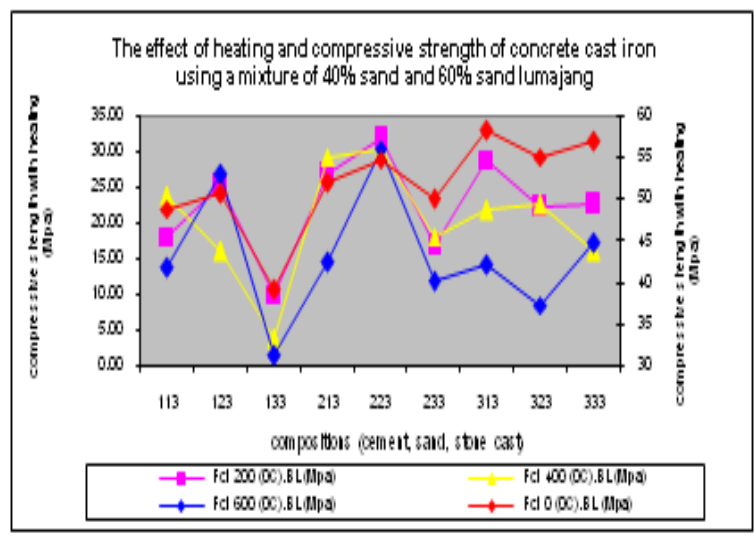

(b)

Fig 4 Effect of heating and compressive strength of concrete cast using, (a) sand iron and (B), (b) $40 \%$ a mixture of grit and $60 \%$ sand lumajang (LB)

\section{Description:}

113 = Stone cast Composition (cement 1, sand and stones cast first 3 parts)

123 = Stone cast Composition (1 cement, 2 of sand and stones cast 3 parts)

133 = Stone cast Composition $(1$ cement, 3 sand and stones cast 3 parts)

213 = Stone cast Composition $(21$ cement, sand and stones cast first 3 parts)

223 = Stone cast Composition $(2$ cement, sand and stones cast 23 parts)

$233=$ Stone cast composition (cement 2, 3 sand and stones cast 3 parts)

313 = Stone cast Composition $(3$ cement, sand and stones cast first 3 parts) 
323 = Stone Cast Composition (3 cement, 2 of sand and stones cast 3 parts)

333 = Stone cast Composition (3 cement, sand and stones cast 33 parts)

From Figure 4 (a), it can be seen that the highest compressive strength of 58.12 MPa 2-1-3 composition using iron sand without heating $\left(0{ }^{0} \mathrm{C}\right)$. At the highest heat treatment at $200{ }^{\circ} \mathrm{C}$ concrete composition of $22.80 \mathrm{MPa} 3-1$ 3 and 2-2-3 later in the composition of 17.60 MPa. At the highest heat treatment at $400{ }^{\circ} \mathrm{C} 2-2-3$ concrete composition of $17.60 \mathrm{MPa}$ and the highest heat treatment at $600{ }^{\circ} \mathrm{C} 2-2-3$ concrete composition of $13.60 \mathrm{MPa}$.

In figure $4(\mathrm{~b})$, the highest heating treatment without the composition of 3-1-3 with a compressive strength of 58.11 $\mathrm{MPa}$. At the highest heat treatment at 200 0C 2-2-3 concrete composition of $31.60 \mathrm{MPa}$. At the highest heat treatment at $400{ }^{0} \mathrm{C} 2-2-3$ concrete composition of $30.40 \mathrm{MPa}$ and the highest heat treatment at $600{ }^{\circ} \mathrm{C} 2-2-3$ concrete composition of $30.40 \mathrm{MPa}$.

\subsection{Ability Testing Composition Heat Cast}

\section{Concrete}

Tests capable of heat carried by providing heat treatment on the composition of the concrete in the kitchen and the measured power is the ability to absorb heat (temperature) and a reduction in heat (temperature). Temperature measurements made by removing material from the electric furnace after reaching the temperature that has been determined, then dilakuan measurements every 1 minute and ten minutes later.

\subsubsection{Heat Able Concrete Composition Testing}

\section{Using Cast Iron Sand}

From the data obtained can be graphed as follows:

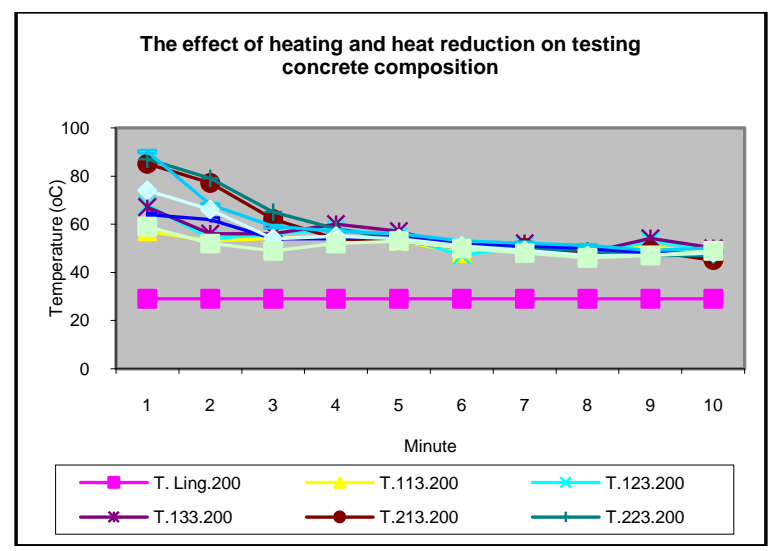

(a)

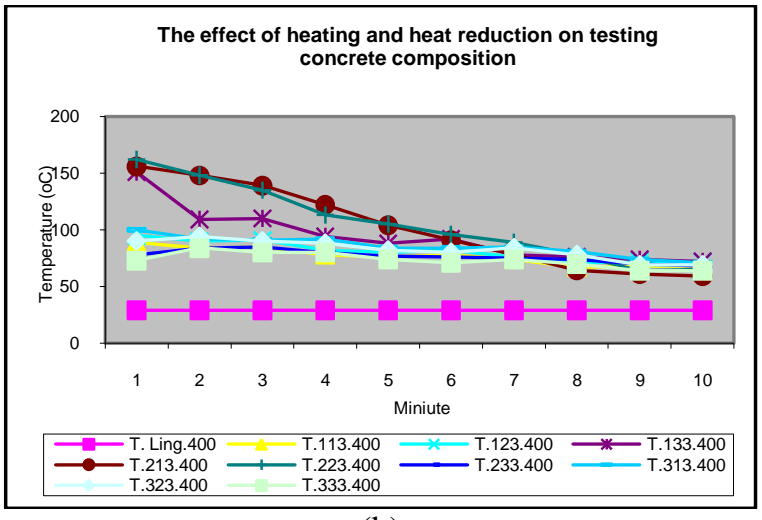

(b)

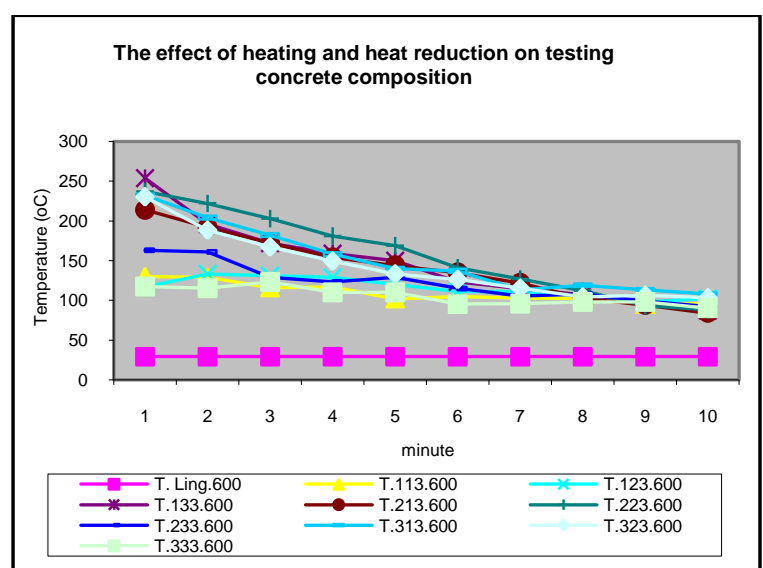

(c)

Fig5. Effect of Heating and Hot decline in Composition Testing Using Concrete Cast Iron Sand (a) Treatment Warming $200{ }^{\circ} \mathrm{C}$, (b) Treatment Warming $200{ }^{\circ} \mathrm{C}$, and (c) Treatment Warming $600{ }^{\circ} \mathrm{C}$.

\subsubsection{Able Heat Composition Testing Using Mixed}

Concrete Cast Iron Sand $\mathbf{4 0 \%}$ and Sand Lumajang $60 \%$

From the data obtained can be graphed as follows:

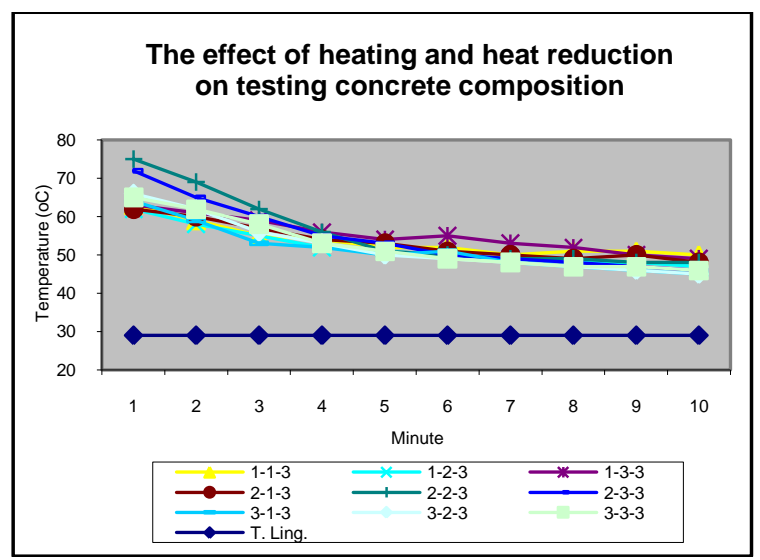

(a) 


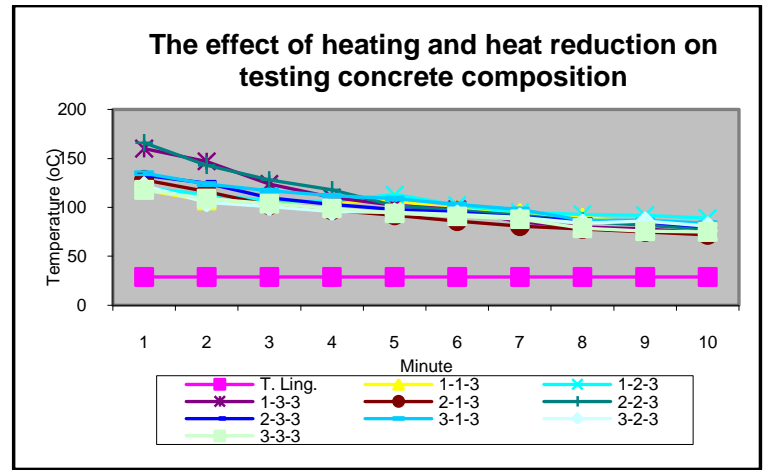

(b)

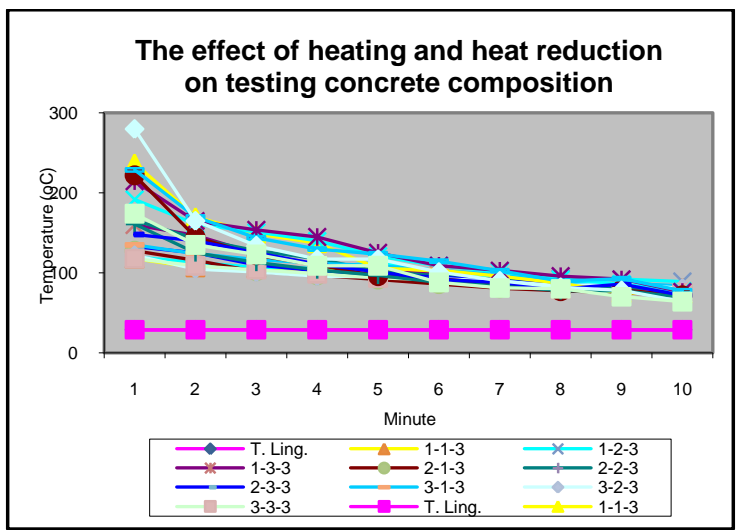

(c)

Fig6. Effect of Heating and Hot decline in Composition Testing Using Mixed Concrete Cast Iron Sand 40\% to $60 \%$ Sand Lumajang (a) Treatment Warming $200{ }^{\circ} \mathrm{C}$, (b) Treatment Warming $200{ }^{\circ} \mathrm{C}$, and (c) Treatment Warming $600{ }^{0} \mathrm{C}$.

From the figure above shows the highest temperature that can be absorbed is owned by 2-2-3 concrete composition on all heat treatment and composition of concrete using iron sand and also on the composition of the concrete using a mixture of $40 \%$ sand with $60 \%$ sand lumajang. This condition is caused by the composition of the solid, so it can be recommended for use as a heat absorber plate of solar radiation.

\subsection{Testing of Solar Radiation Absorption Heat Concrete Cast In Composition}

Testing concrete composition in the heat absorption of solar radiation was done by insulating the room with the glass and coated with sterefoam. The composition of the concrete in the test with a volume of $30 \mathrm{~cm} \times 30 \mathrm{~cm} \times 5 \mathrm{~cm}$ and under the direct rays of the sun's radiation.

\subsubsection{Absorption of Solar Radiation Tests on Concrete Composition Using Cast Iron Sand}

From the test results obtained data, then averaged. And it can be made the following graph:

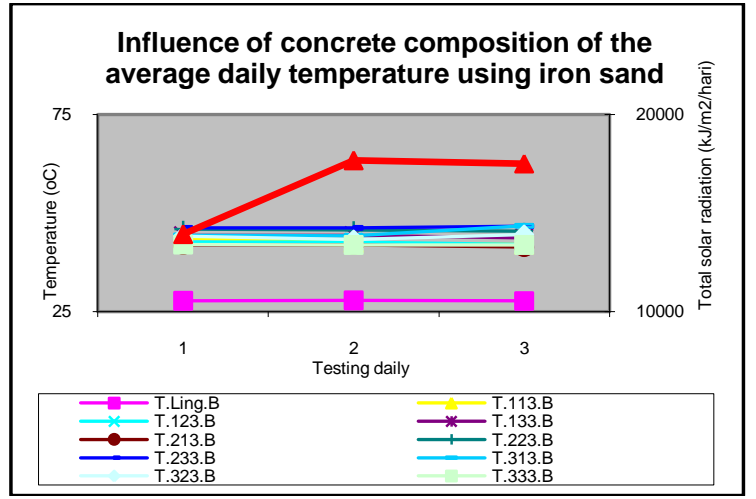

(a)

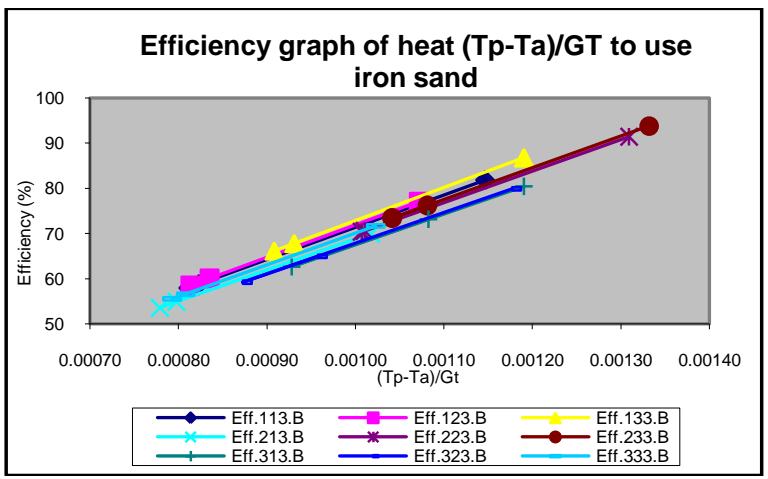

(b)

Fig 7. (a) Graph the influence of concrete composition of the average daily temperature, (b) Graph showing the relationship to the efficient absorption of heat (Tp-Ti) / Gt

From Figure 7 (a), the temperature of concrete composition having a similar pattern, including ambient temperature and solar radiation. The highest temperature is owned by the composition of concrete next to 2-3-3 and 2-2-3 concrete composition. This condition is caused by the composition of the more dense and homogeneous, so that when sunrise to sunset concrete slab heat sink absorbs the heat of solar radiation is higher and when the sun had set up the morning heat absorbing concrete slab off heat to the temperature relative to the ambient temperature.

In figure 7 (b), visible heat absorption efficiency relationship of concrete cast against $(\mathrm{Tp}-\mathrm{Ti}) / \mathrm{Gt}$ highest in the composition of concrete followed by 2-3-3 and 2-2-3 concrete composition. This condition is strongly influenced by the ability of concrete to absorb solar radiation heat, period absorber plates and daily solar radiation.

\subsubsection{Testing of Solar Radiation Absorption in}

\section{Composition Using Mixed Concrete Cast Iron Sand}

\section{$40 \%$ and $60 \%$ sand Lumajang.}

In this assay to see the ability to use a mixture of concrete sand. From the results of the research data and daily averaged, then made the following graph: 


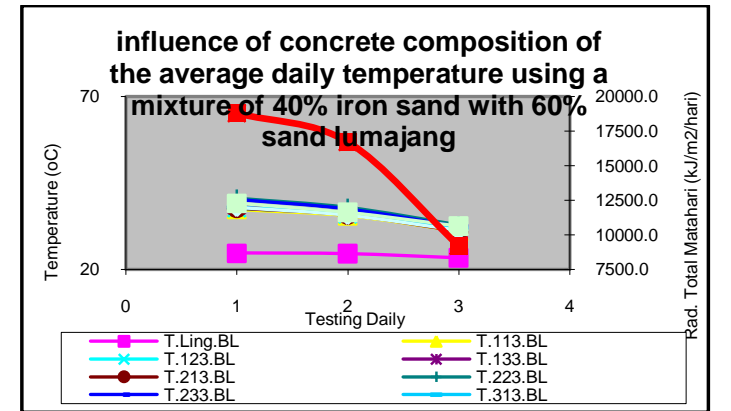

(a)

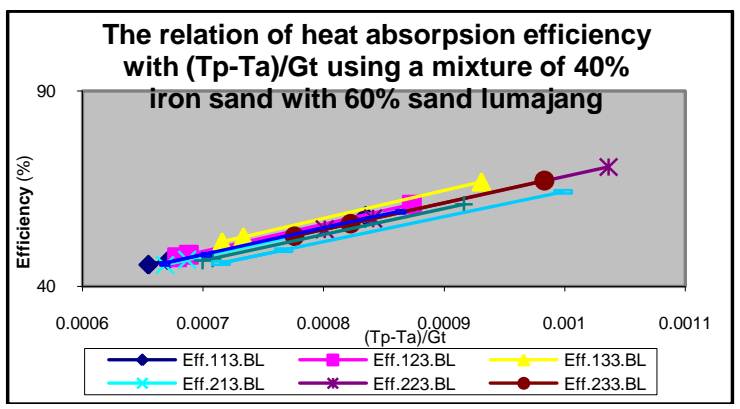

(b)

Fig8. (A) Graph the influence of concrete composition of the average daily temperature using a mixture of sand, (b) Graph showing the relationship to the efficient absorption of heat $(\mathrm{Tp}-\mathrm{Ti}) / \mathrm{Gt}$

From Figure 8 (a), the temperature of concrete composition having a similar pattern with solar radiation. The highest temperature is owned by the composition of 2-2-3 concrete, and later by the concrete composition 2-3-3 and 1-3-3. This condition is caused by the composition of the more dense and homogeneous, so that when sunrise to sunset concrete slab heat sink absorbs the heat of solar radiation is higher and when the sun had set up the morning heat absorbing concrete slab off heat to the temperature relative to the ambient temperature.

In figure 8 (b), visible heat absorption efficiency relationship of concrete cast against (Tp-Ti) / Gt highest in the composition of 2-2-3 concrete, and concrete composition followed by $2-3-3$ and 1-3 -3 . This condition is strongly influenced by the ability of concrete to absorb solar radiation heat, period absorber plates and daily solar radiation.

\subsection{Absorption of Solar Radiation Tests on}

\section{Concrete compositions Best Cast}

In this study, the examinations of the best concrete composition on the heat absorption of solar radiation test use iron sand (B) and a mixture of $40 \%$ iron sand with $60 \%$ lumajang sand (LB). Furthermore, the results of the research data and daily averaged are illustrated by the following graph:

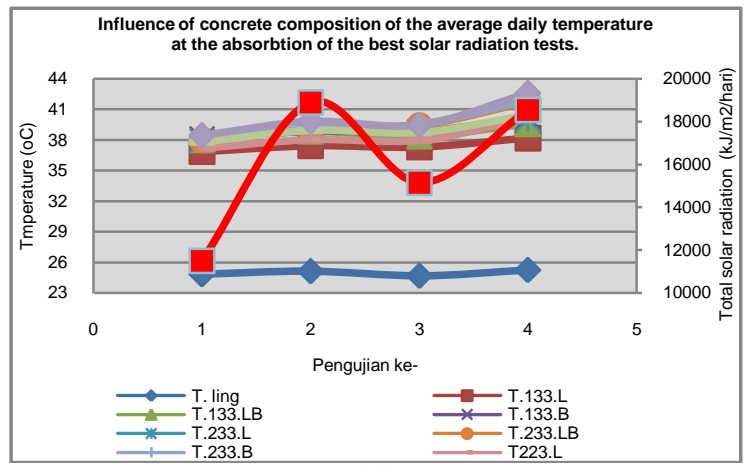

(a)

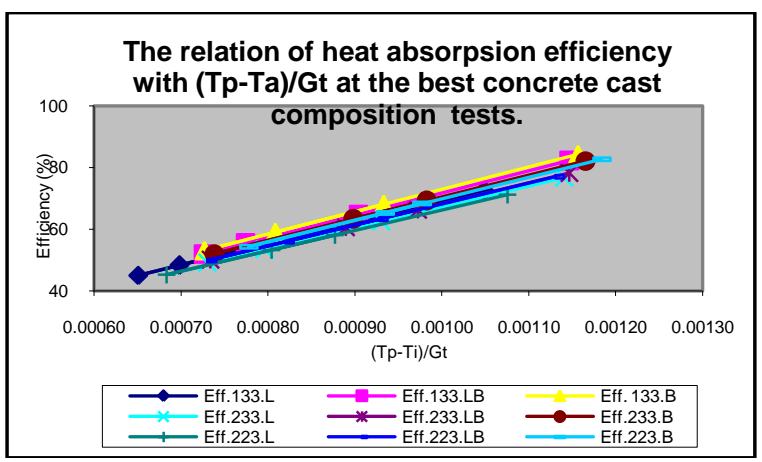

(b)

Fig 9 (a) Graph the influence of concrete composition of the average daily temperature on testing best heat absorption of solar radiation, (b) Graph showing the relationship to the efficient absorption of heat (Tp-Ti) / Gt on testing best composition

From Figure 9 (a), the temperature of concrete composition having a similar pattern with solar radiation. The highest temperature is owned by the composition of 2-2-3 concrete using iron sand, and the next by using a 2-3-3 concrete composition of the iron sand.

In figure 9 (b), visible heat absorption efficiency relationship of concrete cast against (Tp-Ti) / Gt highest in the composition of 2-2-3 concrete using iron sand and is followed by the composition of 2-3-3 concrete using sand iron. This condition is strongly influenced by the ability of concrete to use iron sand to absorb the sun's heat radiation, during absorber plates and daily solar radiation.

\subsection{Cast Concrete Composition Discussion}

From the data and graphs can be discussed on the basis of concrete material heat sink plate solar radiation, as follows:

- On testing the compressive strength and compressive strength without heating by heating to $200{ }^{0} \mathrm{C}$ owned by 3-1-3 composition using a mixture of sand and iron sand and below followed by a 2-2-3 composition. And the compressive strength testing by heating to $400{ }^{0} \mathrm{C}$ and $600{ }^{0} \mathrm{C}$ The highest compressive strength 2-2-3 composition using a mixture of sand and iron sand. The composition of concrete to be used as a hot plate peyerap solar radiation and are in a closed 
room, it will have a warming of the continuous and relatively suppressed due to an increase in temperature in the room, so the composition of 2-23 can be recommended for use as an absorber plate solar radiation heat.

- In the test electric heating obtained in the absorption of heat and then removed to see the ability to absorb heat and decline. From the data obtained using the compositions are too little cement composition is 1-3-3 and 3-1-3 is too much cement cracks, and the results of the test, the best composition adalahkomposisi 2-2-3, this is caused by the composition of the homogeneous and the adequacy of the binding cement sand and stones cast.

- In testing the heat absorption of solar radiation the best composition is also owned by the 2-2-3 composition using iron sand and iron sand mixture with sand lumajang. Condition caused by a homogeneous and solid composition. Using sand in concrete cast iron can increase the ability to absorb solar radiation heat caused by iron sand containing metals, metal properties has a coefficient of heat transfer is faster than the non-metallic materials.

\section{CONCLUSIONS}

From the results of this study concluded that the best concrete composition is the composition of the 2-2-3 concrete compressive strength in the review of the heattreatment, treatment of artificial heating (electric furnace) and the absorption of heat from solar radiation.

\section{ADVICE}

From the results of this study are advised to do more research on:

- Influence on the health properties of metals on the use of concrete as a heat absorber plate of solar radiation that will function on a solar water heater.

- Necessary to test the thickness of the concrete cast of the best of the absorption of solar radiation.

\section{REFERENCES}

[1]. Duffie J.A. dan Beckman W.A. (1980). Solar Engineering Of Thermal Processes. New York: John Willey \& Sons.

[2]. Ismail N. R., (2007), Pengaruh jenis pelat penyerap dan laju aliran terhadap kinerja solar heater sederhana. PHKA2. Teknik Mesin

[3]. Ismail N. R., (2007), Pengaruh jarak dan jumlah ruang penyerap terhadap produktifitas dan efisiensi harian solar still. PDM DIKTI, Jakarta.

[4]. Ismail N. R., dan Aditya C. (2010), Pengaruh komposisi kolektor beton cor dan ketebalan terhadap efisiensi penyerapan panas. PDM DIKTI, Jakarta.

[5]. Ismail N. R., dan Fuhaid N. (2012), Analisa bahan baku beton cor sebagai pelat penyerap panas radiasi matahari. PHB DIKTI. Jakarta.
[6]. Lermpoy K.A. (2003), "Pilot proyek basin tipe solar still dipesisir Probolinggo", Tesis. Malang. Program Pascasarjana Teknik Mesin Univ. Brawijaya Malang.

[7]. Monintja Nita C. V.(2004). "Usaha-usaha untuk meningkatkan efisiensi dan produktifitas solar still". Thesis. Malang: Program Pascasarjana Jurusan Teknik Mesin Unibraw Malang.

[8]. Rahmad Subarkah, (2001), "Penelitian absorber solar still untuk distilasi air laut", Skripsi, Malang: Jurusan Teknik Mesin FT Unibraw Malang 